\title{
Gold Fish (Carassius auratus) Grows Gradually in a Confined Pot Maintained Carefully in all Corners of this World as Popular Hobby
}

\author{
Manju Das ${ }^{1 *}$, Zaman Sufia $^{1}$ and SK Biswas ${ }^{2}$ \\ ${ }^{1}$ Department of Oceanography, Techno India University, West Bengal, India \\ ${ }^{2}$ Department of Civil Engineering, Techno India University, West Bengal, India \\ *Corresponding Author: Manju Das, Department of Oceanography, Techno India \\ University, West Bengal, India.
}

Received: February 22, 2021

Published: March 26, 2021

(C) All rights are reserved by Manju Das., et al.

\begin{abstract}
Gold fish (C. auratus) from family Cypriniformes can adjust in a small confined glass and fibre container to grow gradually. Weight and Length is measured carefully to check growth. Food supplied by the caretaker depends for its growth. Artificial food available in the market (Hobby Centre) in a plastic packet, (MPDA). Small pinch of artificial food in the morning can rare 1 or two fishes in a small fibre aquarium. In the lid perforations help to enter air continuously for mixing with surface water. Need 5 - 6 hrs exposure of air bubble to combat respiration properly. Gills are sensitive for stream-lined fish as fish respire through nostrils located in head. Olfactory rosette most sensitive for fish to feel surroundings.
\end{abstract}

Keywords: C. auratus; Gill; Olfactory Rosette

\section{Introduction}

Gold fish (C. auratus) is very attractive with its 7 fins. Most attractive is caudal fin supported by fin-rays. Bony fish can adjust in fresh water. $\mathrm{pH}$ level is in between 7.6 - 7.9. Slightly alkaline water is suitable. One litre water required to fill the fibre aquarium. USA, Europe, India, China, Japan, Singapore, Malaysia are leading countries to maintain fishes in aquarium as hobby. Indian economy strengthens due to marketing of aquarium fishes. Kolkata in West Bengal is in first place to export aquarium fishes. All other districts get aquarium fishes from Kolkata. MPDA (Marine Fisheries Development Authority) exports aquarium fishes in all states of India. 1.6 million hobbyists like to keep aquarium in house to watch attractive marine as well as fresh water fishes.

\section{Materials and Methods}

Online purchase of fibre aquarium (Flipcart.com) small with 1 lt. water capacity holds Gold fish to watch. Pebbles are required to

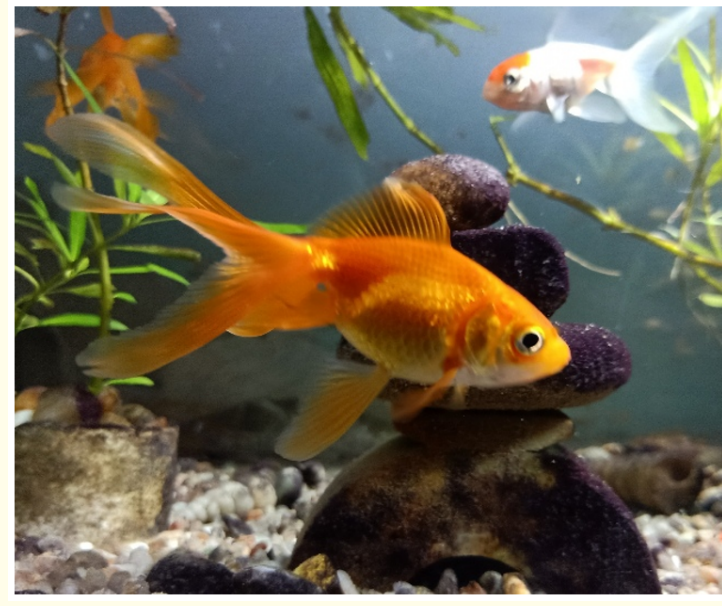

Figure 1: Gold fish (C. auratus) living happily in a confined aquarium (Courtesy Google.com). 
prepare bottom. Their excreta stores in bottom every day. Air pump supplies oxygen to keep Dissolved Oxygen level of limited water. Weekly change of water required to keep fish in a healthy environment. (Biodiversity of Marine Ornamental Fish in West Bengal: Issues of Sustainability and Livelihood Security, B.K. Mahapatra*, U.K. Sarkar** and W.S. Lakra***).

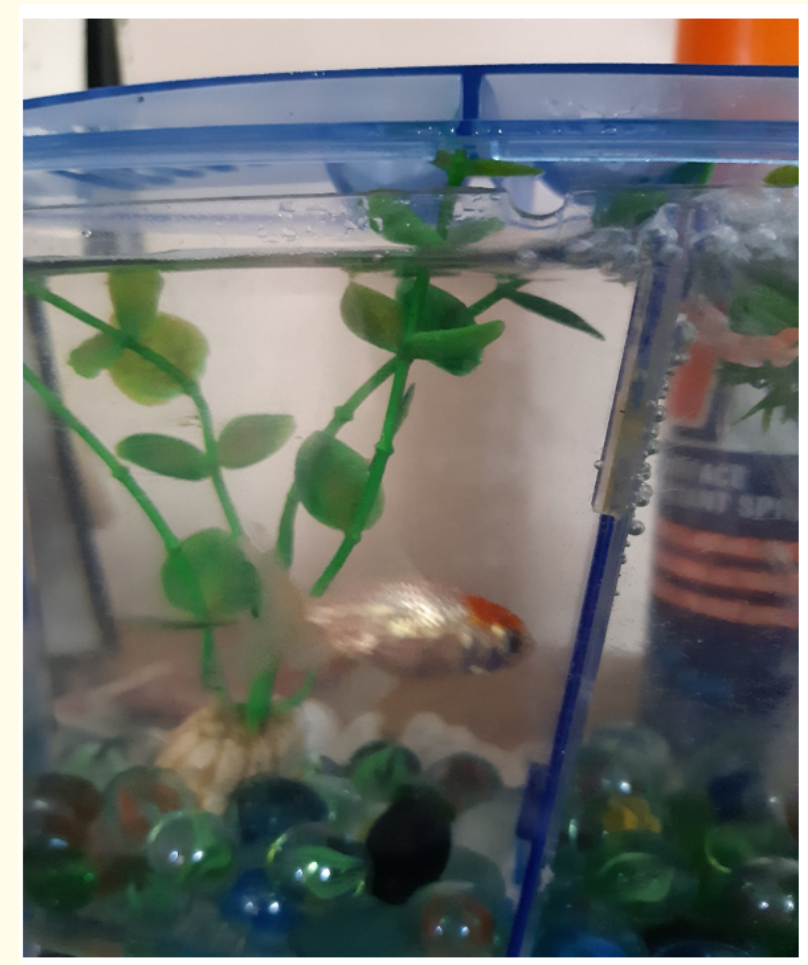

Figure 2: My aquarium fish kept in fibre aquarium (Carassius auratus).

To check growth of my aquarium fish I keep my fish in a small bowl with water and place in digital weighing machine. Initial weight of that container with water is $W_{1}$ and with fish is $W_{2}$. So, the weight of fish is $\mathrm{W}_{2}-\mathrm{W}_{1}=10.7-9.5=1.2 \mathrm{~g}$.

Length of fish is $5 \mathrm{~cm}$. now.

More observation required to keep my pet fish healthy.

\section{Conclusion}

Fish need 24 hours observation. After one month growth will increase according to consumption of dried fish food [1-3].

\section{Bibliography}

1. Mahapatra BK., et al.

2. Tropical fish (Book).

3. Ornamental Gold fish (Carassius carassius) reared easily at home IJFAS.

\section{Assets from publication with us}

- Prompt Acknowledgement after receiving the article

- Thorough Double blinded peer review

- Rapid Publication

- Issue of Publication Certificate

- High visibility of your Published work

Website: www.actascientific.com/

Submit Article: www.actascientific.com/submission.php

Email us: editor@actascientific.com

Contact us: +919182824667 